\title{
Human Resources Management Research from the Perspective of Cost Control in High Star Hotel
}

\author{
Lingmin Fan \\ Tourism Department \\ Xinjiang University of Finance and Economics \\ Urumqi, XinJiang, China \\ E-mail: 903901650@qq.com
}

\author{
Ying Zhang \\ Tourism Department \\ Xinjiang University of Finance and Economics \\ Urumqi, XinJiang, China \\ E-mail: 461424073@qq.com
}

\begin{abstract}
Influenced by the government policy of anti-public corruption, high star-rated hotel industry in our country ran into huge impact, large amount of high star hotels try to control and prevent spreading the negative effects. This paper is going to help high star-rated hotels seek new ways on cost control of human resources management based on the existing research. From the beginning of human resources cost classification, this paper tries to define the classification of high star hotel manpower cost control. This paper builds the basis of the quantitative models and analyzes the current situation of human resource management cost control by the model. Quantitative analysis concludes hotel organization should add creative department, pay attention to the development of versatile type of employees, and provide more clear space for the development of the hotel staff. Three strategies of human resource management can effectively reduce the cost of the hotel human resources management, so that high star hotels improve profit margins.
\end{abstract}

\section{Keywords-cost control; high star hotel; human resources}

\section{INTRODUCTION}

The rules of central eight of the government against public corruption generated, more and more high star hotels received the unprecedented challenge. For example, the income of 12 five-star hotels in Urumqi catering since December 2012 has significantly fallen: YinDu Hotel fell $40 \% \sim 50 \%$, Hyde Hotel fell about 40\%, RuiHao Hotel was as high as $60 \%$ drop rate. To get rid of relying on public consumption, high star hotels need to choose new strategies to minimize the effects of the policy. Enterprise's growth and success are derived from reasonable and optimized human resources management. Therefore, strengthening the high star hotel human resources management research is imminent at present. This article will begin with the analysis of human resource management to provide some new ways to high star-rated hotels.

\section{THE CURRENT RESEARCH STATUS OF High STAR HOTEL HUMAN RESOURCES MANAGEMENT}

Using CNKI Search Engine sort out literature research about cost control of the hotel management began in 2005 . In the initial stage, economy hotel and catering cost is object. After that, high star hotel cost research gradually entered into the vision of scholars, but most of the academic research focused on the star hotel operation strategy and business performance. Since then, the research on the hotel cost control gradually towards economics, finance business administration, accounting and other disciplines of academic research, but on high star hotel research still very lack. In 2011, the focus of research on that is the economy hotel, little concern for high star hotel. After action against public corruption, academic research on star hotel cost control research had the remarkable development, but rarely discussed the cost of human resources management alone.

The whole research on cost control in the tourism enterprise makes great achievements. By analyzing the existing essays, we can sort out that the hotel on human resource management research mainly concentrated on liquidity of the human resources, hotel human resources management, hotel staff satisfaction and education training, psychological authorization, etc. Xingling Fan expressed new spirit from the perspective of liquidity of human resources, according to the statistics analysis of a tourism association, and gained the actual turnover of tourism in our country enterprise human resources, then he summarized the characteristics of the flow of personnel and the reasons and put forward the reasonable view on controlling tourism enterprises to build the management system of human resource flow. Xueqiang Peng based on the knowledge of economy era-- the concept of "people-oriented", used strengths management strategies in our country hotel situation of tourism enterprises, such as questionnaire survey. According to the survey results, it is concluded that the necessity of LIFO professional training and achieving personal goals including enterprises win-win. Qinsi Tian, ZhuZhu started from how to improve employee satisfaction, then wanted to establish effective management system to make managers participate in decision-making, and established competitive salary system.

This paper based on the current international hotel what is going on and existing research results and from the perspective of cost control analyzes human resources management research, and hopes to reduce the human resources management cost of high star hotel. At the same time, it will provide new ideas and new references to managers. 


\section{The COST OF Human Resources IN High StAR HOTEL}

\section{A. Human Resources Cost}

Human resources cost has broad conception and narrow conception. Narrow sense of the human resource cost is just to show an enterprise in a certain period of time, in the production, management and service provided by using labor and payment paid in direct or indirect investment and allocation in the cost of the workers. This article does the study from a perspective of narrow sense to make quantitative simulation research, so that the high star hotel can deal with the present situation of revenues plunged by cutting the costs of the hotel human resources management to improve the profits to get through the hard time of hotel business recession.

\section{B. Human Resources Cost of High Star Hotel}

When Wayne Fascio. analyzed human resources cost, he gave a clear definition that human resource cost was spending fee which an enterprise in order to achieve their organizational goals, and to create the best economic and social benefits, and obtain, develop, use and safeguard the necessary human resources. This view almost summarizes all aspects on the human resources cost. In reference to the academic literature, most of the human resources costs are divided into five parts: acquisition cost, development cost, use cost, security cost and the cost of office. In the high star hotel, the human resources cost is also divided into five parts.

Acquisition cost is the price which high star hotel needs the human resources, mainly including the personnel recruitment, selection, hiring and so on. Such as the advertisement cost, office cost during the personnel selection charge; hiring fee which is suitable for the employees; new employees of labor and management fees, etc.

The cost of development is to make the employees meet the requirements of specific jobs and improve the hotel staff work ability, work efficiency and service quality, and mainly through this way of training so that employees have the jobs done. Development cost is the most important part of human resource cost,and it includes pre-service training, on-the-job training and off-job training cost.

The using cost is a hotel employee compensates energy both physical and mental consumption, including maintaining cost, incentive cost and adjusting cost. Maintain cost is employee's wages, allowances and bonuses; rewards cost such as the excessive work of employees bonuses; adjusting cost is paid to employees to spa.

Security cost ensures employee's right will exist when the employee loss of short-term or long-term use value, including labor accident security, health care, retirement security, unemployment insurance costs. These costs generally occur in the formal employees.

The cost of leaving the hotel is the fee paid for employees' leave allowances and suspended because of the job losses, including severance costs, inefficient cost and vacant position before leaving. Severance costs refer to the hotel fire staff compensation fees; the inefficient cost is that the staff leave hotel caused by the low efficiency of work before leaving; vacant position cost refers to the employee turnover or job vacancy.

\section{The Establishment OF Hotel COST CONTROL QUANTITATIVE ANALYSIS MODEL}

\section{A. The Construction of the Model}

After finishing defining the each cost of the hotel human resources management, this paper will establish a set of scientific researches on the quantitative model. Assume the total cost of human resources management for $\mathrm{C} . \mathrm{C} 1, \mathrm{C} 2, \mathrm{C} 3$, $\mathrm{C} 4$ and C5 respectively stands for the acquisition cost, development cost, use cost, security cost and the office cost. The purpose of human resource management in high star hotel is to reduce some cost according to actual condition, at the same time ensure the stability of income level, and constantly to take measures to increase profits so that the hotel will gain long-term development opportunity.Assume the data of paying the cost increase in revenue for the corresponding $\mathrm{S} 1, \mathrm{~S} 2, \mathrm{~S} 3, \mathrm{~S} 4, \mathrm{~S} 5$. In view of the costs involved, function model is set up:

$$
\begin{aligned}
& \mathrm{C}=\mathrm{C} 1+\mathrm{C} 2+\mathrm{C} 3+\mathrm{C} 4+\mathrm{C} 5 \\
& \mathrm{~S}=\mathrm{S} 1+\mathrm{S} 2+\mathrm{S} 3+\mathrm{S} 4+\mathrm{S} 5 \\
& \mathrm{P}=\mathrm{S}-\mathrm{C}
\end{aligned}
$$

$\mathrm{P}$ is profit, something which has nothing to do with the human resource management is not considered, our research points to cost control and the resulting revenue and profit on human resource management.

\section{B. Improving Human Resource Management in High Star-level Hotel Model}

This paper refers to every cost is out of public funds to support, and the human resources management of cost control is set in a certain period of time (in the quarter, half year or one year for inspection cycle). The benefit and corresponding cost will be a certain period of variable quantity, in order to develop strategies to reduce costs and increase the hotel's revenue so as to increase profits for the hotel and get opportunities. There are first and second cycle. Human resource management under the first cycle is not taken measures, the second cycle is to take the cost of human resources management earnings after taking measures. Assume profits of first inspection cycle for the $\mathrm{P}$ ', the second review cycle profit of $\mathrm{P}$ ', so the model expression is:

$$
\begin{aligned}
& \mathrm{C}=\mathrm{C} 1+\mathrm{C} 2+\mathrm{C} 3+\mathrm{C} 4+\mathrm{C} 5 \\
& \mathrm{~S}=\mathrm{S} 1+\mathrm{S} 2+\mathrm{S} 3+\mathrm{S} 4+\mathrm{S} 5 \\
& \mathrm{P}=\mathrm{S}-\mathrm{C} \\
& \mathrm{P}^{\prime}>\mathrm{P}^{\prime \prime}
\end{aligned}
$$

Four formulas should be set up at the same time in order to achieve the research target. 


\section{THE NEW STRATEGY FOR HUMAN RESOURCES MANAGEMENT OF High STAR Hotel COST CONTROL}

\section{A. Add the creative department in the organization}

High star-rated hotels have already recognized the high-end luxury positioning is difficult to support the future survival and development after the great shock. So they start to face the public and businessmen. This change makes part of main business in the high star hotel change traditional scope, towards to diversified development, such as wedding, birthday feast, a full moon banquet, dinner banquet topic.To build themes of the external environment and design meticulously to grab customers, the high star hotel needs to increase outside hotel staff, the resulting acquisition cost will increase, name $\mathrm{C} 12$. $\mathrm{C} 12$ is mainly composed of selection fee, hiring fee and employee relocation costs; the resulting revenue is $\mathrm{S} 12$.The new employees' pre-service training, such as adding decoration designer for birthday feast and sound control. It occurs $\mathrm{C} 22$, corresponding the income increase S22. As the time goes, C12, C22 will continue decreasing under the action of a marginal, while S12 and S22 basically remain unchanged, it leads to:

$$
\begin{aligned}
& \mathrm{S} 12+\mathrm{S} 22-(\mathrm{C} 12+\mathrm{C} 22)>\mathrm{S} 11+\mathrm{S} 21-(\mathrm{C} 11+\mathrm{C} 21) \\
& \mathrm{P}^{\prime \prime}>\mathrm{P}^{\prime}
\end{aligned}
$$

At this time, $\mathrm{P}$ 'may be greater than zero and less than or equal to zero. But positive earnings or negative loss under this policy is an optimal choice.

According to the model, multiple theme activities are making and external costs converted to the internal costs as a strategy in the long run.This model can conclude add creative department as a dependent department in the organization is a new strategy. This strategy can combine the acquisition cost of human resources with development costs turn into the cost of product development, and guarantee the continued vitality of star hotel products.

\section{B. Pay attention to the development of versatile type of employees}

Some high star-rated hotel, according to the broadcast, in the western region own the guests amounted to less than $20 \%$, while guests are over $60 \%$ before last year's holiday .High star hotel is a kind of sensitive tourism enterprise, the quantity of consumers and occupancy rate will be influenced by many factors, so it is very difficult to accurately predict its change. Banquet sharply decline will lead use cost of $\mathrm{C} 3$ also decline sharply in the short term. To analyze and predict by using the model , from the use of $\mathrm{C} 3$, if the hotel staff owns simple skills, when the hotel runs into a crisis, such as "anti-public corruption" experience splendidly unsubscribed, food and beverage employees will be the part of the idle, which is under the condition of invariable in C3, S31 will decline, while profits will fall; But if some employees have several skills needed, this part of the idle C3 will translates into higher than S31, much better than the first cycle. From the cost of employee turnover in C5, versatile type staff will be better than simple staff in the hotel meeting the same crisis. Be fired by the hotel cost control probability are much smaller than simple staff, spending before leaving inefficient will greatly reduce. Cost of the two reactions in the model as follows:

$$
\begin{aligned}
& \mathrm{S} 32>\mathrm{S} 31, \mathrm{C} 32=\mathrm{C} 31, \mathrm{C} 52<\mathrm{C} 51 \\
& (\mathrm{~S} 32-\mathrm{C} 32)+(\mathrm{S} 52-\mathrm{C} 52)>(\mathrm{S} 31-\mathrm{C} 31)+(\mathrm{S} 32-\mathrm{C} 31) \\
& \mathrm{P}^{\prime \prime}>\mathrm{P}^{\prime}
\end{aligned}
$$

It is wise to train staff on the several-hands employees in high star hotel to reduce the cost of the hotel human resources, and cultivate employees can be adjusted according to actual needs to solve the problems about inefficiency and lack of standardization of temporary workers; Although it needs pay more in the initial stage, it is "key card" in high star hotel. And it is more suitable for adjustment of employees to reduce departure cost, so it must be a very significant intangible asset.

\section{Provide clear spaces with the hotel staff for their development}

"Anti-public consumption" policy brought many questions for unemployment of high star hotel. Many high star hotels fired many frontline employees and managers for the reverse, and spent a lot of money on calling in outside "overseas background," "high reputation" executives, and firmly believed that high investment must bring high benefits. Using the model for the manpower policy concerns on the introduction of $\mathrm{C} 1, \mathrm{C} 2$ and $\mathrm{C} 5$, we make an example for a veteran employees leaving due to introducing external executives. Older workers have enough ability to competent quests, hotel's loyalty and recognition more than outsiders. If the hotel human resources management is based on external executives, old employees will feel hopeless because they can't see the promotion space. The C5 has two parts, one is inefficient costs before experienced employees leaving, another is vacant position cost. Set the first cycle to use of layoffs and external staff reforms, the second cycle use the adjustment of internal staff work of human resources crisis management. The first cycle of $\mathrm{C} 5$ reduced spending will bring $\mathrm{S} 5, \mathrm{C} 1$ and $\mathrm{C} 2$ will increase.

$$
\begin{aligned}
& \mathrm{C} 12=0, \mathrm{C} 22=0, \quad \mathrm{C} 52=0 \\
& \mathrm{C}^{\prime \prime}=\mathrm{C} 52+\mathrm{C} 12+\mathrm{C} 22 \\
& \mathrm{~S}^{\prime}=\mathrm{S} 11+\mathrm{S} 21+\mathrm{S} 51 \\
& \mathrm{~S} 12>\mathrm{S} 11, \mathrm{~S} 22>\mathrm{S} 21, \\
& \mathrm{~S} 11-\mathrm{C} 11+\mathrm{S} 21-\mathrm{C} 21+\mathrm{S} 51-\mathrm{C} 51>\mathrm{P}^{\prime} \\
& \mathrm{P}^{\prime \prime}>\mathrm{P}^{\prime}
\end{aligned}
$$

Because outsiders will spend the acquisition cost and development costs, the first cycle spend on old employees of $\mathrm{C} 1$ and $\mathrm{C} 2$ would be sunk costs. External personnel cost of replacement cost on departure cost adds to the cost of human resources management in the further, profit decreases in the short period. According to the existing research results, employees with a clear development space is an important strategy to retain employees and easy to adopt the strategy of high star-rated hotels at present stage.

\section{ACKNOWLEDGMENT}

NFC (40961008); CNTA (Cultivation Plan for Tourism Industry Expert). 


\section{REFERENCES}

[1] Xinling Fan, Human Resources Management of Liquidity and Management Countermeasures in Tourism Enterprises analysis, Coastal Enterprises with Science and Technology[J]. 2008 (12) : $80-83$.

[2] Xueqiang Peng, the Use of Strengths Management Strategy on Human Resources Management in Tourism Enterprises, Central South Forestry College Journal[J]. 2004 (3) : 5-9.

[3] Qinsi Tian, ZhuZhu, How to Improve Employee's Satisfaction in Tourism Enterprises, Trade in China[J]. 2011 (4) : 161-162.

[4] David P Lepak, Scott A Snell. Virtual HR. Strategic Human Resource Management in the 21st Century [J].Human Resource Management Review,1998(3):p215-234.

[5] Delery J.E. and Doty D.H. Models of Theorizing in Strategy Human Resource Management Tests of Universalistie, Contingency, and Configurational Performance Predictions[J].Academy of Management Journal,VOI.39,1996. 